\title{
Evaluation of the Antibacterial and Phytochemical Activity of Ripe and Unripe Orange Peels (Citrus sinensis and Citrus aurantium)
}

Turay, A. A ${ }^{1}$, Braimoh, K. $\mathrm{O}^{1}$, Iyevhobu, K. $\mathrm{O}^{1 *}$, Obodo, B. $\mathrm{N}^{1}$, Udoaka, A. $\mathrm{M}^{2}$, Erazua, O. $\mathrm{P}^{3}$, Ovbiebo, E. L ${ }^{4}$, Ignatius, S. $\mathrm{S}^{4}$

\footnotetext{
${ }^{1}$ Department of Medical Laboratory Science, Ambrose Alli University, Ekpoma, Edo State, Nigeria

${ }^{2}$ Department of Medical Laboratory Science, Federal Medical Centre, Ebute-Metta, Lagos State, Nigeria

${ }^{3}$ Medicaid Radiodiagnostic, Abuja, Nigeria

${ }^{4}$ Department of Microbiology, Ambrose Alli University, Ekpoma, Edo State, Nigeria
}

*Corresponding author: Iyevhobu, K. O

Abstract

Citrus fruits are rich in bioactive compounds such as vitamin C, carotenoids, flavonoids, vitamin B complex and minerals which are highly beneficial to human's health. This study was carried out to evaluate the invitro antibacterial and phytochemical activities of ripe and unripe orange peels extract on selected microorganisms. These microorganisms include Escherichia coli, Staphylococcus aureus, Pseudomonas aeruginosa, Klebsiella pneumoniae, Streptococcus spp., Proteus spp. and Enterobacter spp. isolated from urinary tract infections and wound swabs of patients that visited Irrua Specialist Teaching Hospital, (ISTH) Irrua, Edo State. A stock concentration of each successive orange peel extract was obtained using alcohol (95\% ethanol $+5 \%$ methanol) and $100 \%$ methanol (absolute). These extracts along with positive and negative controls were tested for the presence of active phytochemicals. The result showed that the zones of inhibitions were significantly higher with methanol extract than alcohol extract against the test organisms. The zone of inhibition of all extracts against the test pathogenic organisms showed a significant increase as the concentration of the extract increased. The minimum inhibitory concentrations of the methanol and alcohol peel extracts ranged between $6.25-12.5 \mathrm{mg} / \mathrm{ml}$ while the minimum bacteriocidal concentrations ranged between $12.5-25 \mathrm{mg} / \mathrm{ml}$. Invitro investigations confirmed the antimicrobial potential of Citrus sinensis and Citrus aurantium peels against pathogenic bacteria. It is therefore recommended that further in vivo studies should be done to determine the exact dosage and its effectiveness in practical situations along with toxicity studies.

Keywords: Antibacterial, phytochemical, Citrus, Peels, invitro, microorganisms.

Copyright $\odot 2020$ The Author(s): This is an open-access article distributed under the terms of the Creative Commons Attribution 4.0 International License (CC BY-NC 4.0) which permits unrestricted use, distribution, and reproduction in any medium for non-commercial use provided the original author and source are credited.

\section{INTRODUCTION}

Over the years, fruits are regarded as an important aspect of diet and used extensively for the production of food products such as salads and fruit based drinks [1]. Fruits are equally known to contain some important bioactive ingredients such as vitamin $\mathrm{C}$, carotenoids, flavonoids, minerals and vitamin B complex which play significant role in ameliorating the effect of some disease $[2,1]$.

Citrus belong to the Rutaceae family and consist of over 140 genera and 1,300 species where Citrus sinensis (sweet orange) and Citrus aurantium (sour orange) is included as one of the important fruits of the genus Citrus [3]. They are well known as one of the world's major food crops that are produced in tropical and subtropical countries such as Brazil, USA,
Japan, China, Mexico, Pakistan and countries of the Mediterranean region [4, 2].

The citrus peel is seen as an important by product in the citrus processing industries where large amounts are produced and considered as wastes. However, citrus essential oil is one of the by-products of citrus where they are used to give flavor to drinks and foods. It is an integral component for the pharmaceutical industry for the preparation of drugs, soaps, perfumes and other cosmetics as well as for home cleaning products [5]. The citrus peels is divided into the epicarp (flavedo) and mesocarp (albedo) where the epicarp is the outermost surface of the peel while the mesocarp is the white, soft inner layer of the peel [6, 7]. The citrus peels contain high quantity of phenolic compounds such as flavonoids and is known to exhibit various antimicrobial and antioxidant activities $[5,8,9]$. 
There are several reports on the medical properties of citrus where its use in historical medical practice has been reported in various countries such as China, India, Japan and Africa [10-13]. In addition, plant extracts and phytochemicals with antimicrobial activity have been used as therapeutics over the years [14] and known to possess antibacterial activity [15-17].

Considering the various reports on the phytochemical and antibacterial properties of plant extracts, therefore study is aimed at evaluating the antibacterial and phytochemical activities of ripe (Citrus sinensis) and unripe orange peels (Citrus aurantium).

\section{Materials and Methods Collection of Citrus Fruits}

The ripe and unripe fruits of Citrus aurantium (bitter orange) and C. sinensis (sweet orange) that are free from insect infestation and other kinds of damages were collected from plant farms in Ekpoma Esan West Local Government Area, Edo state, Nigeria. The specimens were further identified and authenticated by Department of Botany, Ambrose Alli University, Ekpoma.

\section{Extraction}

The fruits were washed several times with distilled water and were then peeled off carefully using a sharp knife avoiding any damage of the oil glands. Peels were separated, cut into small pieces, dried under shade and grinded into powder [18]. A known quantity of each peel powder $(1 \mathrm{~g})$ was added into separate sterile bottle containing $10 \mathrm{ml}$ of the various diluents; water (hot and cold), alcohol (95\% ethanol $+5 \%$ methanol), ether and $100 \%$ methanol (absolute), and left for 48 hours with occasional stirring. The content of flask was filtered through sterile Whatman No. 1 filter paper and evaporated to dryness. The condensed peel extracts were used for determining antimicrobial activity [19].

\section{Phytochemical Analysis}

A stock concentration of $1 \%(\mathrm{~W} / \mathrm{V})$ of each successive extract obtained using alcohol (95\% ethanol $+5 \%$ methanol) and $100 \%$ methanol (absolute) were prepared using the respective solvents. These extracts along with positive and negative controls were tested for the presence of active phytochemicals such as alkaloids, cardiac glycosides, flavonoids, phlobatannins, reducing sugars, saponins, starch/polysaccharide, steroids, tannins, and terpenoids following standard methods [20, 21]:

\section{Source of Bacterial Isolates}

The different test organisms were isolated from urine and wound swab from clinical samples of patient that visited Irrua Specialist Teaching Hospital (ISTH) Irrua, Edo State. They were analyzed in the Medical Diagnostic Laboratory, College of Medical Sciences, Ambrose Alli University, Ekpoma, Edo State within a period of four months (May 2019 - August 2019). The test organisms isolated for the study include; Escherichia coli, Staphylococcus aureus, Klebsiella pneumonia, Streptococcus species, Pseudomonas aureginosa, Proteus spp and Enterobacter species.

\section{Identification of Test Organisms}

All isolates were identified by their colonial appearance on the media, gram staining reaction and biochemical tests [22]. Catalase test was done on Gram positive cocci. Catalase negative Gram positive cocci in chains were identified as Streptococcus species while the catalase positive cocci in clusters were identified as Staphylococcus species. Coagulase test was carried out on all the catalase positive cocci. The coagulase positive organisms were identified as Staphylococcus aureus while the coagulase negative organisms were identified as Staphylococcus albus. For the Gram negative bacilli, overnight broth cultures were made by adding the colonies to sterilized peptone water and incubated for 24 hours at $37^{\circ} \mathrm{C}$ and motility test was done. For nonlactose fermenting Gram negative bacilli that are motile, oxidase test was done. For lactose fermenting Gram negative bacilli that are motile indole test was done. For those colonies that were lactose fermenters and oxidase negative, urease test was performed on them [22].

\section{Preparation of Test Organisms}

The different organism isolated; Staphylococcus aureus, Klebsiella pneumonia, Streptococcus species, Proteus species, Pseudomonas aeruginosa and Escherichia coli and Enterobacter spp were sub-cultured into peptone water overnight before antibiogram extract testing.

\section{Antimicrobial (Antibiogram) Activity Test}

The antibacterial properties of the extracts was tested against each isolate comprising of both Grampositive and Gram-negative organism using disc diffusion method as described by Kirby-Baur [23].

\section{Sensitivity Testing of Citrus Peel Extract}

The sensitivity testing of the plant extract was determined using the disc diffusion method as described by Kirby-Bauer [23]. The antimicrobial disc were locally prepared by punching out disc $6 \mathrm{~mm}$ in diameter from a good quality Whatman no 1 filter paper and was sterilized for 15 minutes with autoclave. The bacterial isolates were first inoculated in peptone water and incubated for 8 hours and sub-cultured on nutrient agar, excess broth was tilled off and allowed to dry. Using a sterile forceps, the prepared sterile disc was picked and impregnated with the various extracts in $1 \mathrm{mg} / \mathrm{ml}$ and the disc placed on the inoculated agar plate equidistant from each other alongside with a locally prepared antibiotic disc (Gentamycin) as positive control and diluents as negative control. It was incubated at $37^{\circ} \mathrm{C}$ for 24 hours in an incubator and inhibition zone (IZ) was measured by using ruler calibrated in millimeters. 


\section{Minimum Inhibitory Concentration (MIC)}

The tube dilution method described by Cowan and Steel [24] was used. The minimum inhibitory concentration gave the lowest concentration of the aqueous extract that can inhibit the growth of bacteria isolates. $1 \mathrm{ml}$ prepared nutrient broth was dropped into the test tube 2 to $10,1 \mathrm{ml}$ of the extract was added to tube 1 and 2. Serial dilutions were made resulting to decreasing concentration of the aqueous extract. The extract in tube 3 was diluted until tube 9 from which $1 \mathrm{ml}$ was discarded. $1 \mathrm{ml}$ of the test bacteria was added to all the tubes from tube 2 to tube 10. Tube1 which contain nutrient broth and organism serves as control tube [25]. The entire procedure was done for the isolates that were susceptible to the extracts with zone of inhibition above. The tubes were thoroughly mixed and incubated at $37^{\circ} \mathrm{C}$ for 24 hours after which they were examined for visible growth which is seen as turbidity. The MICs reported as the lowest concentration of the plants extracts that prevent visible growth [22].

\section{Minimum Bactericidal Concentration (MBC)}

The minimum bactericidal of Citrus peel extract was determined with little modification, by obtaining samples in the MIC assay and Sub-cultured onto freshly prepared nutrient agar medium and incubated at $37^{\circ} \mathrm{c}$ for 24 hours. The MBC was taken as the lowest concentration of the extract that did not show any visible bacterial growth on the surface of the agar plate [22].

\section{Antimicrobial Activity Test}

The antimicrobial properties of the extracts were tested against each isolate comprising of both gram-positive and gram-negative organism using disc diffusion test (Kirby-Bauer) method.

\section{RESULTS}

The results showed that the hot and cold aqueous extracts of Citrus sinensis and Citrus aurantium showed no antimicrobial activity against any of the test organisms while the methanol and alcohol extract shows significant antimicrobial activities against Escherichia coli, Staphylococcus aureus, Pseudomonas aeruginosa., Klebsiella pneumoniae, Streptococcus spp., Proteus spp. and Enterobacter spp. Also the ether extract of both fruit samples only showed significant antimicrobial activities against Klebsiella pneumonia (Table-1).

The Minimum Inhibitory Concentration (MIC) and the Minimum Bactericidal Concentration (MBC) of C. sinensis and Citrus aurantium peel extracts (Methanol and alcohol) was shown to be between 6.25 $-12.5 \mathrm{mg} / \mathrm{ml}$ and $12.5-25 \mathrm{mg} / \mathrm{ml}$ respectively (Tables 2 and 3).

The phytochemical analysis of the peel extracts of C. sinensis and C. aurantium revealed the presence of alkaloids, reducing sugars, steroids and terpenoids amongst others (Table-4).

Table-1: Antimicrobial activities of Citrus sinensis and Citrus aurantium extracts against the test organisms

\begin{tabular}{|c|c|c|c|c|c|c|c|c|c|}
\hline \multirow{2}{*}{\multicolumn{2}{|c|}{ Fruit sample }} & \multirow{2}{*}{$\begin{array}{l}\text { Sample } \\
\text { Extracts }\end{array}$} & \multicolumn{7}{|c|}{ Zones of inhibition (mm) against test organisms } \\
\hline & & & $\begin{array}{l}\text { Escherichia } \\
\text { coli }\end{array}$ & $\begin{array}{l}\text { Staphylococcus } \\
\text { aureus }\end{array}$ & $\begin{array}{l}\text { Pseudomonas } \\
\text { aeruginosa }\end{array}$ & $\begin{array}{l}\text { Klebsiella } \\
\text { pneumonia }\end{array}$ & $\begin{array}{l}\text { Streptococcus } \\
\text { spp. }\end{array}$ & $\begin{array}{l}\text { Proteus } \\
\text { spp. }\end{array}$ & $\begin{array}{l}\text { Enterobacter } \\
\text { spp. }\end{array}$ \\
\hline \multirow{10}{*}{$\begin{array}{l}\text { Citrus } \\
\text { sinensis }\end{array}$} & \multirow[t]{5}{*}{ Ripe } & Methanol & 13 & 0 & 15 & 15 & 12 & 17 & 16 \\
\hline & & Alcohol & 14 & 0 & 14 & 0 & 12 & 11 & 13 \\
\hline & & Ether & 0 & 0 & 0 & 13 & 0 & 0 & 0 \\
\hline & & $\begin{array}{l}\text { Cold } \\
\text { water }\end{array}$ & 0 & 0 & 0 & 0 & 0 & 0 & 0 \\
\hline & & $\begin{array}{l}\text { Hot } \\
\text { water }\end{array}$ & 0 & 0 & 0 & 0 & 0 & 0 & 0 \\
\hline & \multirow[t]{5}{*}{ Unripe } & Methanol & 0 & 0 & 14 & 11 & 9 & 12 & 14 \\
\hline & & Alcohol & 17 & 0 & 17 & 0 & 11 & 12 & 10 \\
\hline & & Ether & 0 & 0 & 0 & 0 & 0 & 0 & 0 \\
\hline & & $\begin{array}{l}\text { Cold } \\
\text { water }\end{array}$ & 0 & 0 & 0 & 0 & 0 & 0 & 0 \\
\hline & & $\begin{array}{l}\text { Hot } \\
\text { water }\end{array}$ & 0 & 0 & 0 & 0 & 0 & 0 & 0 \\
\hline \multirow{10}{*}{$\begin{array}{l}\text { Citrus } \\
\text { aurantium }\end{array}$} & \multirow[t]{5}{*}{ Ripe } & Methanol & 0 & 0 & 0 & 14 & 9 & 11 & 15 \\
\hline & & Alcohol & 0 & 17 & 10 & 10 & 0 & 10 & 0 \\
\hline & & Ether & 0 & 0 & 0 & 0 & 0 & 0 & 0 \\
\hline & & $\begin{array}{l}\text { Cold } \\
\text { water }\end{array}$ & 0 & 0 & 0 & 0 & 0 & 0 & 0 \\
\hline & & $\begin{array}{l}\begin{array}{l}\text { Hot } \\
\text { water }\end{array} \\
\end{array}$ & 0 & 0 & 0 & 0 & 0 & 0 & 0 \\
\hline & \multirow[t]{5}{*}{ Unripe } & Methanol & 0 & 0 & 0 & 0 & 0 & 0 & 0 \\
\hline & & Alcohol & 0 & 0 & 0 & 0 & 0 & 0 & 0 \\
\hline & & Ether & 0 & 0 & 0 & 13 & 0 & 0 & 0 \\
\hline & & $\begin{array}{l}\text { Cold } \\
\text { water }\end{array}$ & 0 & 0 & 0 & 0 & 0 & 0 & 0 \\
\hline & & $\begin{array}{l}\text { Hot } \\
\text { water }\end{array}$ & 0 & 0 & 0 & 0 & 0 & 0 & 0 \\
\hline Control & \multicolumn{2}{|c|}{ Gentamicin } & 23 & 18 & 20 & 23 & 25 & 17 & 20 \\
\hline
\end{tabular}


Table-2: The Minimum Inhibitory Concentration (MIC) of Citrus sinensis and Citrus aurantium extracts (methanol and alcohol) against test organisms

\begin{tabular}{|c|c|c|c|c|c|c|c|c|c|}
\hline \multirow[t]{2}{*}{ Test organism } & \multicolumn{2}{|l|}{ Extracts } & \multicolumn{7}{|c|}{ Concentration of extracts $(\mathrm{mg} / \mathrm{ml})$} \\
\hline & & & 100 & 50 & 25 & 12.5 & 6.25 & 3.125 & MIC ( $\mathrm{mg} / \mathrm{ml})$ \\
\hline \multirow{2}{*}{ Escherichia coli } & Alcohol & Ripe C. sinensis & - & - & - & - & - & + & 6.25 \\
\hline & & Unripe C. sinensis & - & - & - & - & - & + & 6.25 \\
\hline Staphylococcus aureus & Alcohol & Ripe C. aurantium & - & - & - & - & - & + & 6.25 \\
\hline \multirow[t]{3}{*}{ Pseudomonas aeruginosa } & Alcohol & Unripe C. sinensis & - & - & - & - & - & + & 6.25 \\
\hline & & Ripe C. sinensis & - & - & - & - & + & + & 12.5 \\
\hline & & Ripe C. aurantium & - & - & - & - & + & + & 12.5 \\
\hline \multirow[t]{2}{*}{ Klebsiella pneumonia } & Methanol & Ripe C. aurantium & - & - & - & - & - & + & 6.25 \\
\hline & & Ripe C. sinensis & - & - & - & - & - & + & 6.25 \\
\hline \multirow[t]{2}{*}{ Streptococcus spp. } & Alcohol & Ripe C. sinensis & - & - & - & - & + & + & 12.5 \\
\hline & & Unripe C. sinensis & - & - & - & - & + & + & 12.5 \\
\hline \multirow[t]{3}{*}{ Proteus spp. } & Methanol & Ripe C. sinensis & - & - & - & - & + & + & 12.5 \\
\hline & & Unripe C. sinensis & - & - & - & - & - & + & 6.25 \\
\hline & & Ripe C. aurantium & - & - & - & - & + & + & 12.5 \\
\hline \multirow[t]{3}{*}{ Enterobacter spp. } & Methanol & Ripe C. sinensis & - & - & - & - & - & + & 6.25 \\
\hline & & Unripe C. sinensis & - & - & - & - & - & + & 6.25 \\
\hline & & Ripe C. aurantium & - & - & - & - & + & + & 12.5 \\
\hline
\end{tabular}

Key: - = No turbidity, + = Turbidity

Table-3: The Minimum Bacteriocidal Concentration (MBC) of Citrus Sinensis and Citrus aurantium extracts (methanol and alcohol) against test organisms

\begin{tabular}{|l|l|l|l|l|l|l|l|l|l|l|}
\hline Test organism & \multicolumn{3}{l}{ Extracts } & \multicolumn{6}{l|}{ Concentration of extracts (mg/ml) } \\
\hline & & & 100 & 50 & 25 & 12.5 & 6.25 & 3.125 & MBC (mg/ml) \\
\hline Escherichia coli & Alcohol & Ripe C. sinensis & - & - & - & + & + & + & 25 \\
\hline & & Unripe C. sinensis & - & - & - & - & + & + & 12.5 \\
\hline Staphylococcus aureus & Alcohol & Ripe C. aurantium & - & - & - & - & + & + & 12.5 \\
\hline Pseudomonas aeruginosa & Alcohol & Unripe C. sinensis & - & - & - & - & + & + & 12.5 \\
\hline & & Ripe C. sinensis & - & - & - & + & + & + & 25 \\
\hline & & Ripe C. aurantium & - & - & - & + & + & + & 25 \\
\hline Klebsiella pneumonia & Methanol & Ripe C. aurantium & - & - & - & + & + & + & 25 \\
\hline & & Ripe C. sinensis & - & - & - & + & + & + & 25 \\
\hline & & & & & & & & & \\
\hline Streptococcus spp. & Alcohol & Ripe C. sinensis & - & - & - & + & + & + & 25 \\
\hline & & Unripe C. sinensis & - & - & - & + & + & + & 25 \\
\hline Proteus spp. & Methanol & Ripe C. sinensis & - & - & - & + & + & + & 25 \\
\hline & & Unripe C. sinensis & - & - & - & + & + & + & 25 \\
\hline & & Ripe C. aurantium & - & - & - & + & + & + & 25 \\
\hline Enterobacter spp. & Methanol & Ripe C. sinensis & - & - & - & - & + & + & 12.5 \\
\hline & & Unripe C. sinensis & - & - & - & - & + & + & 12.5 \\
\hline & & Ripe C. aurantium & - & - & - & + & + & + & 25 \\
\hline
\end{tabular}

Key: - = No Growth, + = Significant Growth.

Table-4: The Phytochemical Constituents Present in extracts of ripe and unripe Citrus sinensis and Citrus aurantium

\begin{tabular}{|l|l|l|l|l|l|l|l|l|l|}
\hline \multirow{2}{*}{ Phytochemical constituent } & \multicolumn{3}{l}{ Citrus sinensis } & \multicolumn{3}{l|}{ Citrus aurantium } \\
\cline { 2 - 11 } & Ripe & Unripe & \multicolumn{2}{l|}{ Ripe } & \multicolumn{2}{l|}{ Unripe } \\
\hline & Alc & Meth & Alc & Meth & Alc & Meth & Alc & Meth \\
\hline Alkaloids & + & + & + & + & + & ++ & + & + \\
\hline Reducing sugar & ++ & ++ & ++ & ++ & ++ & ++ & ++ & ++ \\
\hline Phlobatannin & - & - & - & - & - & - & - & - \\
\hline Saponins & - & - & - & + & - & + & - & - \\
\hline Steroid & ++ & ++ & ++ & ++ & ++ & ++ & ++ & ++ \\
\hline Starch & + & + & + & + & - & - & + & + \\
\hline Flavonoids & - & + & + & ++ & + & + & - & + \\
\hline Terpenoids & + & + & + & + & ++ & ++ & + & + \\
\hline Hydrolysable tannin & + & + & + & - & + & + & + & + \\
\hline Condensed tannin & + & + & + & + & + & + & + & + \\
\hline Cardiac glycoside & +++ & ++ & +++ & ++ & ++ & ++ & ++ & ++ \\
\hline
\end{tabular}

Key: Alc = Alcohol, Meth $=$ Methanol, $-=$ Absent, $+=$ Fairly Present, $++=$ Moderately Present, $+++=$ Highly Present. 


\section{DisCUSSIONS}

It is without doubts that there have been various reports on the medicinal importance of plants, but however there is still need to standardize these medicinal plants according to the modern parameters to ensure their activity and efficacy.

In this study, the methanol and alcohol extracts of Citrus sinensis and Citrus aurantium showed greater antibacterial activity as compared to the water extracts. Also, ether extracts of both fruit samples only showed significant antimicrobial activities against Klebsiella pneumonia, Staphylococcus aureus which were found to be resistant to all extracts except the alcohol ripe Citrus aurantium extracts. Moreover, minimum inhibitory concentrations of the alcohol extracts were lesser than the methanol extracts. These observations are line with the studies of Ellof [26] and Nagarajappa et al., [27]. Nair et al., [28] and Nisha et al., [29] also reported better antibacterial activity with orange peel extract prepared in organic solvent.

The zones of inhibitions were significantly higher with Methanol extract than with Alcohol extract against the test organisms. However, Nisha et al., [29] reported that the potency of citrus fruit peel is enhanced by the type of solvent used where he indicated that there are some active ingredients in orange peel which have high antimicrobial effect but which would not be released except when orange fruit peel is used in conjunction with a particular solvent. The zones of inhibition of all extracts against the test organisms increased significantly as the concentration of the extract increased. This is in agreement with the studies of Vivek et al., [30] and Lawal et al., [31] where they reported similar trend of the result.

The minimum inhibitory concentrations of Citrus sinensis and Citrus aurantium methanol and alcohol extracts tested ranges between 6.25-12.5 $\mathrm{mg} / \mathrm{mL}$, while the minimum bacteriocidal concentration ranges between $12.5-25 \mathrm{mg} / \mathrm{ml}$. The MIC values obtained are much lower than that obtained by Lawal et al., [31] against Salmonella typhi, Salmonella paratyphi and Aeromonas hydrophila. The difference in findings may be due to the differences in the type of isolates tested. In this study, none of the organisms were sensitive to the cold and hot water extracts for both the Citrus sinensis and Citrus aurantium. Klebsiella pneumonia was the only organism sensitive to Citrus sinensis ether extract and Staphylococcus aureus was only sensitive to Citrus aurantium alcohol extract in the study. E. coli was only sensitive to ripe Citrus sinensis methanol and alcohol extract and unripe Citrus sinensis alcohol extract in the study. Pseudomonas aeruginosa was only sensitive to ripe Citrus sinensis methanol and alcohol extract, unripe Citrus sinensis methanol and alcohol extract and Citrus aurantium alcohol extract. Enterobacter spp. was only sensitive to Citrus sinensisripe methanol and alcohol extract, Citrus sinensis unripe methanol and alcohol extract and Citrus aurantium methanol extract.

These antimicrobial potencies of the citrus plants could be attributed to the presence of tannins, saponins, phenolic compounds, essential oils and flavonoids [32]. Tannin as observed in Citrus sinensis and Citrus aurantium extract have been found to form irreversible complexes with proline rich protein [33] resulting in the inhibition of cell protein synthesis. Parekh and Chanda [34] reported that tannins are known to react with proteins to provide the typical tanning effect which is important for the treatment of inflamed or ulcerated tissues. Another secondary metabolite observed in the alcohol extract was alkaloid. The biological property of alkaloids is to exhibit toxicity against cells of foreign organisms which have been employed in the reduction and elimination of human cancer cell lines [35]. Just et al., [36] revealed the inhibitory effect of saponins on inflamed cells and was found to be present in the extracts of Citrus sinenesis and Citrus aurantium peel. Flavonoids was reported to be present in the citrus extracts and known to possess biological activities like anti-inflammatory, antimicrobial, anti-angionic, analgesic, cytostatic, antioxidant properties and anti-allergic functions [37].

\section{Conclusion}

The results of this study gave substantial evidence that the extracts were active against Escherichia coli, Staphylococcus aureus, Pseudomonas aeruginosa, Klebsiella pneumoniae, Streptococcus spp., Proteus spp. and Enterobacter spp. The minimum inhibitory concentrations of the methanol and alcohol peel extracts ranged between $6.25-12.5 \mathrm{mg} / \mathrm{ml}$ while the minimum bacteriocidal concentrations ranged between $12.5-25 \mathrm{mg} / \mathrm{ml}$. The phytochemical analysis revealed the presence of alkaloids, tannins, reducing sugars, steroids, flavonoids and terpenoids.

\section{ACKNOWLEDGEMENTS}

Our special thanks to all the authors, who contributed to the success of this research and the presentation of this manuscript and to St Kenny Consult for creating the enabling environment and proof reading this manuscript.

Financial Support and Sponsorship: Nil.

Conflicts of Interest: There are no conflicts of interest.

\section{REFERENCES}

1. Ghasemi K, Ghasemi Y, Ebrahimzadeh MA. Antioxidant activity, phenol and flavonoid contents of 13 citrus species peels and tissues. Pak J Pharm Sci. 2009 Jul 1;22(3):277-81.

2. Ramful D, Bahorun T, Bourdon E, Tarnus E, Aruoma OI. Bioactive phenolics and antioxidant 
propensity of flavedo extracts of Mauritian citrus fruits: Potential prophylactic ingredients for functional foods application. Toxicology. 2010 Nov 28;278(1):75-87.

3. Mandalari G, Bennett RN, Bisignano G, Saija A, Dugo G, Lo Curto RB, Faulds CB, Waldron KW. Characterization of flavonoids and pectins from bergamot (Citrus bergamia Risso) peel, a major byproduct of essential oil extraction. Journal of agricultural and food chemistry. 2006 Jan 11;54(1):197-203.

4. Anwar F, Naseer R, Bhanger MI, Ashraf S, Talpur FN, Aladedunye FA. Physico-chemical characteristics of citrus seeds and seed oils from Pakistan. Journal of the American Oil Chemists' Society. 2008 Apr 1;85(4):321-30.

5. Okwu DE, Emenike IN. Evaluation of the phytonutrients and vitamin contents of citrus fruits. Int. J. Mol. Med. Adv. Sci. 2006;2(1):1-6.

6. Jayaprakasha GK, Girennavar B, Patil BS. Radical scavenging activities of Rio Red grapefruits and Sour orange fruit extracts in different in vitro model systems. Bioresource technology. 2008 Jul 1;99(10):4484-94.

7. Siddique S, Shafique M, Parveen Z, Khan SJ, Khanum R. Volatile components, antioxidant and antimicrobial activity of Citrus aurantium var. bitter orange peel oil. Pharmacology online. 2011;2:499-507.

8. Adnan M, Umer A, Ahmad I, Hayat K, Shakeel S. In vitro evaluation of biological Activities of Citrus leaf extracts. Sains Malaysiana. 2014 Feb 1;43(2):185-94.

9. Parashar S, Sharma H, Garg M. Antimicrobial and antioxidant activities of fruits and vegetable peels: A review. Journal of Pharmacognosy and Phytochemistry. 2014 May 1;3(1): 160-164.

10. Harborne JB. Indian Medicinal Plants. A Compendium of 500 Species. 1; Warrier PK, Nambiar VPK, Ramankutty C. Eds.), Journal of Pharmacy and Pharmacology. 1994; 46:935.

11. Aibinu I, Adenipekun $\mathrm{T}$, Adelowotan $\mathrm{T}$, Ogunsanya T, Odugbemi T. Evaluation of the antimicrobial properties of different parts of Citrus aurantifolia (lime fruit) as used locally. African Journal of Traditional, Complementary, and Alternative Medicines. 2007;4(2):185-190.

12. Hirota R, Roger NN, Nakamura H, Song HS, Sawamura M, Suganuma N. Anti- inflammatory effects of limonene from yuzu (Citrus junos Tanaka) essential oil on eosinophils. Journal of Food Science. 2010 Apr;75(3):H87-92.

13. Zhou XM, Wen GY, Zhao Y, Liu YM, Li JX. Inhibitory effects of alkaline extract of Citrus reticulata on pulmonary fibrosis. Journal of ethnopharmacology. 2013 Mar 7;146(1):372-8.

14. Prabuseenivasan S, Jayakumar M, Ignacimuthu S. In vitro antibacterial activity of some plant essential oils. BMC complementary and alternative medicine. 2006 Dec 1;6(1):39.
15. Dhanavade MJ, Jalkute CB, Ghosh JS, Sonawane KD. Study antimicrobial activity of lemon (Citrus lemon L.) peel extract. British Journal of pharmacology and Toxicology. 2011 Aug;2(3):119-22.

16. Bansode DS, Chavan MD. Studies on antimicrobial activity and phytochemical analysis of citrus fruit juices against selected enteric pathogens. International Research Journal of Pharmacy. 2012 Nov;3(11):122-6.

17. Madhuri S, Hegde AU, Srilakshmi NS, Prashith Kekuda TR. Antimicrobial activity of Citrus sinensis and Citrus aurantium peel extracts. Journal of Pharmaceutical and Scientific Innovation (JPSI). 2014;3(4):366-8.

18. Dugo P, Mondello L, Dugo L, Stancanelli R, Dugo G. LC-MS for the identification of oxygen heterocyclic compounds in citrus essential oils. Journal of Pharmaceutical and Biomedical Analysis. 2000 Dec 1;24(1):147-54.

19. Borgmann S, Niklas DM, Klare I, Zabel LT, Buchenau P, Autenrieth IB, Heeg P. Two episodes of vancomycin-resistant Enterococcus faecium outbreaks caused by two genetically different clones in a newborn intensive care unit. International journal of hygiene and environmental health. 2004 Jan 1;207(4):386-9.

20. Sofowora AE. Medicinal Plants and Traditional Medicine in Africa. $2^{\text {nd }}$ ed. Sunshine Hous, Ibadan, Nigeria: Spectrum Books Ltd; Screening Plants for Bioactive Agents. 1993; 134-156.

21. Evans WC, Trease GE. Volatile oils and resins. Trease and Evans Pharmacognosy. 2002:253-88.

22. Cheesbrough, M. (2006): Antimicrobial sensitivity testing in: District laboratory practice in Tropical countries. Cheesbrough, M. (ed). Part 2, Cambridge university press.p. 319-335.

23. Bauer AW. Kirby Bauer method antimicrobial susceptibility testing by a standardized single disk method. American journal of clinical pathology. 1966;45(4):493-6.

24. Cowan, S.T. and Steel, K.J. (1985): Antibiotic sensitivity In: Cowan Steel's manual for identification. Cambridge university press, London New York.Pp 24.

25. Nester, E. W., Roberts, L. E., Pearsall, N. N., Anderson, D. G. and Nester, M. T. (2004): Antimicrobial medicine: In Keven T. K., Ronald., E. N., Terrace, S., Jode, K. B. (eds). Microbiology A human perspective $2^{\text {nd }}$ edition, Von Hoffman press Inc, University of Washington, New York. Pp 447-521.

26. Ellof J.N. (1998): Which extractant should be used for the screening and isolation of antimicrobial components from plants? J. Ethnopharmacol.; 60: $1-8$.

27. Nagarajappa R., Batra M., Sharda A.J., Asawa K., Sanadhya S, Daryani H, Ramesh G. (2013): Antimicrobial Effect of Jasminum grandiflorum L. and Hibiscus rosa-sinensis L. Extracts Against 
Pathogenic Oral Microorganisms - An in vitro comparative study. Oral Health Prev. Dent. 10(3)290-306

28. Nair R., Kalariya T., and Sumitra C. (2005): Antibacterial activity of some selected Indian medicinal flora. Turk. J. Biol.; 29: 41-47.

29. Nisha S.N., Swedha A.A., and Rahaman J.S.N. (2013): Antibacterial activity of citrus sinensis peel against enteric pathogens. IJPRBS; 2(5): 113.

30. Vivek K.R., Nandin, S.S. and Anitha S. (2010): Anti-typhoid activity of aqueous extract of fruit peel Citrus sinensis (L). IJ PRD; 2(9): 31-42.

31. Lawal D., Bala J.A., Aliyu S.Y., and Huguma M.A. (2013): Phytochemical Screening and In Vitro Anti-Bacterial Studies of the Ethanolic Extract of Citrus Senensis (Linn.) Peel against some Clinical Bacterial Isolates.International Journal of Innovation and Applied Studies; 2 (2): 138-145.

32. Aboaba, O. and Efuwape, B.M. (2001): Antibacterial Properties of Some Nigerian Species. Bio. Res. Comm.; 13: 183-188.
33. Shimada T. Salivary proteins as a defense against dietary tannins. Journal of chemical ecology. 2006 Jun 1;32(6):1149-63.

34. Parekh J, Chanda S. In vitro antibacterial activity of the crude methanol extract of Woodfordia fruticosa Kurz. Flower (Lythraceae). Brazilian Journal of Microbiology. 2007 Jun;38(2):204-7.

35. Nobori T, Miura K, Wu DJ, Lois A, Takabayashi $\mathrm{K}$, Carson DA. Deletions of the cyclin-dependent kinase-4 inhibitor gene in multiple human cancers. Nature. 1994 Apr 21;368(6473):753-6.

36. Just MJ, Recio MC, Giner RM, Cuéllar MJ, Máñez S, Bilia AR, Ríos JL. Anti-inflammatory activity of unusual lupane saponins from Bupleurum fruticescens. Planta medica. 1998 Jun;64(05):404-7.

37. Hodek P, Trefil P, Stiborova M. Flavonoids potent and versatile biologically active compounds interacting with cytochrome P450. Chemico-Biol Intern; 2002; 139(1): 1-21. 